\title{
Effect of low-dose macrolide antibiotics on theophylline disposition in pediatric patients
}

\author{
Yoshifusa Abe ${ }^{1)}$, Yuko Nanri ${ }^{1)}$, Hideyasu Oto ${ }^{1)}$, Taeru Kitabayashi ${ }^{1)}$, Shuichiro Watanabe ${ }^{1)}$, \\ Yasuhei Odajima ${ }^{2)}$, Kazuo Itabashi ${ }^{1)}$, Harumi Takahashi ${ }^{3)}$, and Hirotoshi Echizen ${ }^{3)}$ \\ ( ${ }^{1)}$ Department of Pediatrics, Showa University School of Medicine), \\ ( ${ }^{2)}$ Department of Pediatrics, Saitama Medical University), and \\ $\left({ }^{3)}\right.$ Department of Pharmacotherapy, Meiji Pharmaceutical University, Tokyo, Japan)
}

Summary: Low-dose macrolide antibiotics are administered for the treatment of certain chronic inflammatory sinopulmonary diseases (e.g., sinusitis and panbronchiolitis). Because 14-membered ring macrolide antibiotics administered at antimicrobial doses have been suggested to elicit a significant inhibitory effect on the hepatic metabolism of theophylline, we studied whether low-dose macrolide antibiotic therapy also evokes a clinically relevant alteration in the disposition of theophylline. The steady-state serum theophylline concentration and the urinary concentrations of theophylline and its metabolites [i.e., 1-methyluric acid (1MU), 3-methylxanthine (3MX), 1,3-dimethyluric acid (DMU), and caffeine] were examined in nine stable asthmatic children who received both theophylline and lowdose erythromycin or clarithromycin $(12.3 \pm 4.5 \mathrm{mg} / \mathrm{kg}$ body weight/day) and in ten children who received theophylline alone. An immunoassay and high-performance liquid chromatography with ultraviolet detection (HPLC-UV) were used for serum and urinary drug assay, respectively. Results demonstrated no significant differences in serum theophylline concentration, the metabolic clearance of theophylline to its metabolites, and the renal clearance of theophylline between the two groups. In conclusion, the administration of low-dose macrolide antibiotics for the treatment of sinopulmonary diseases would not stipulate a dosage reduction of concomitantly administered theophylline in pediatric patients

\section{小児患者のテオフィリン体内動態におよぼす 少量マクロライド療法の影響}

\author{
阿部 祥英 ${ }^{1)}$, 南里 祐子 ${ }^{1)}$, 大戸 秀恭 ${ }^{1)}$, 北林 耐 $^{1)}$, 渡邊修一郎 ${ }^{11}$ \\ 小田島安平 ${ }^{2}$, , 板橋家頭夫 ${ }^{1)}$, 高橋 晴美 $^{3)}$, 越前 宏俊 ${ }^{3)}$ \\ ( ${ }^{1)}$ 昭和大学医学部小览科), ( ${ }^{2}$ 埼玉医科大学小巟科), ( ${ }^{3)}$ 明治薬科大学薬物治療学)
}

要旨：少量マクロライド療法は副鼻腔炎や沉細気管支炎のような慢性気道炎症に対して行われる。 14員環マクロライド抗菌薬を治療量で投与するとテオフィリンの肝代謝が有意に阻害されるが, 我々 は少量マクロライド療法もテオフィリン代謝に臨床的に影響のある変化を及ぼすのかどうかを検討

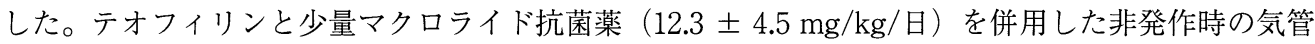
支喘息患児 9 名とテオフィリン単独投与の患児 10 名を対象として，定常状態でのテオフィリン濃度 
とテオフィリンおよびその代謝産物尿中濃度を測定した。血中および尿中濃度はそれぞれ免疫測定 法, 高速液体クロマトグラフ法で測定した。両群間でテオフィリン血中濃度, テオフィリンの代謝 クリアランス，腎クリアランスに有意差はなかった。よって，小児の呼吸器疾患に対する少量マク ロライド療法を行う際, 併用するテオフィリン投与量の減量は必要ないと判断された。

Key word : theophylline, urinary theophylline metabolites, low-dose macrolide antibiotics, drug interaction, asthma

\section{Introduction}

Macrolide antibiotics are commonly prescribed for the treatment of upper and lower respiratory tract infections caused by various pathogenic organisms at oral doses of 30-50 $\mathrm{mg} / \mathrm{kg}$ body weight/day in children or $1-2 \mathrm{~g} /$ day in adults ${ }^{1)}$. In addition, a long-term low-dose (e.g., approximately $50 \%$ less than the standard anti-infective dose) administration of these drugs is considered an important adjunct in the treatment of various upper and lower respiratory tract diseases (e.g., chronic sinusitis, diffuse panbronchiolitis, bronchiectasis, and cystic fibrosis) owing to their remarkable effects of promoting and sustaining the tissue reparative process in inflammation ${ }^{2}$. Possible mechanisms underlying these distinct actions of macrolide antibiotics may be associated with the downregulation of the host inflammatory response to tissue injuries ${ }^{3)}$.

There is concern about possible drug interactions in low-dose macrolide antibiotic therapy, because 14-membered ring macrolide antibiotics (e.g., erythromycin, and clarithromycin) at standard doses interfere with the hepatic metabolism of many drugs $s^{5}$. In particular, their interaction with theophylline is of clinical interest, because theophylline has a rather narrow therapeutic range $(10-20 \mu \mathrm{g} / \mathrm{mL})$ and its toxicity could be potentially fatal ${ }^{6}$. To our knowledge, however, there is a paucity of information on whether low-dose macrolide antibiotic therapy is associated with a clinically relevant drug interaction with theophylline in pediatric pa- tients.

Theophylline undergoes extensive hepatic metabolism; it is converted to 1, 3-dimethyluric acid (DMU) by cytochrome P450 1A2 (CYP1A2), $2 \mathrm{E} 1$, and $3 \mathrm{~A} 4$, and to 3-methylxanthine (3MX) and 1-methylxanthine by CYP1A2 ${ }^{7)}$. . 1-Methylxanthine is subsequently oxidized to 1-methyluric acid (1MU) by xanthine oxidase ${ }^{7}$. Because these metabolites are recovered in urine, the metabolic clearance of the metabolites of theophylline serve as useful indices of the in vivo activity of distinct CYP isoforms involved in the formation of respective metabolites ${ }^{9}$. In this context, we determined whether low-dose macrolide antibiotics alter the systemic disposition of theophylline and the urinary indices of CYP isoform activity in pediatric patients. Here, we present that low-dose macrolide antibiotics can be safely administered without clinically relevant interference with theophylline disposition.

\section{Patients and study design}

Eighteen pediatric patients (14 males and 4 females) who were admitted to Showa University Hospital owing to an acute exacerbation of asthma or bronchitis participated in the study. After their asthmatic symptoms had subsided, they received a sustained-release formula of theophylline (Theodur ${ }^{\circledR}$ ) for a round-the-clock theophylline therapy. When the study was performed, none of the patients had a body temperature of $37.5^{\circ} \mathrm{C}$ or higher, or crackles or wheezing upon auscultation. None exhibited any signs or symptoms indicative of congestive heart failure. The patients were divided into 
two groups according to their clinical conditions: nine of the 18 patients who exhibited persistent signs and symptoms of sinusitis received low-dose macrolide therapy (the macrolide-antibiotic-treated group) and the remaining patients were administered theophylline alone (the control group). One patient (No. 5) initially assigned to the control group was subsequently placed into the macrolide-antibiotic-treated group when she was admitted to the hospital owing to asthma attacks with signs of sinusitis. Another patient (No. 7) was considered to have chromosomal anomaly of trisomy 21. The macrolide antibiotics (i.e., erythromycin for 8 patients and clarithromycin for one patient) were administered orally twice daily. Clarithromycin and erythromycin were in dry syrup formulation $\left(\right.$ Clarith $^{\circledR}$ ) and dry syrup as ethylsuccinate (Erythrocin ${ }^{\circledR}$ ), respectively. During the study period, the patients received no other medications that might have affected the disposition of theophylline (e.g., anticonvulsants, rifampicin, and quinolone antibiotics). None of the patients exhibited abnormal liver or renal function as determined by routine blood biochemistry (Table 1). None showed complications of clinical conditions that may have altered theophylline clearance (e.g., dehydration, hypoxia, acidosis, viral infections, and acute febrile illness) ${ }^{6)}{ }^{10)}$. Informed consent was obtained from either one or both parents of each child before enrollment in the study. The study was approved by the ethics committee of Showa University School of Medicine.

Blood and urine samples for the measurement of theophylline or its metabolites were obtained from the children at least 3 days after the initiation of theophylline therapy to ensure the attainment of the steady-state. Blood samples were drawn 3.5 - 6 hours after the oral administration of theophylline. Serum theophylline concentration was measured by fluorescence polarization immunoassay $\left(\mathrm{TDX}^{\circledR}\right.$, Abbott Laboratories, Chicago) in the Clinical
Biochemistry Laboratory, Showa University Hospital. Because of difficulties in collecting urine samples from children, the collection periods of urine samples varied among the patients. Nonetheless, urine volume was measured and a portion of each urine sample was stored at $-30^{\circ} \mathrm{C}$ before performing the assay. The urinary concentrations of theophylline, 1-methyluric acid (1MU), 3-methylxanthine (3MX), 1,3-dimethyluric acid (DMU), and caffeine were measured as follows. To a $50-\mu \mathrm{L}$ urine sample, $300 \mu \mathrm{L}$ of $0.01 \mathrm{M}$ acetate buffer (pH 4.0) and $50 \mu \mathrm{L}$ of $1 \mathrm{mg} / \mathrm{mL} \beta$-hydroxyethyltheophylline (IS) were added. Then, the sample was extracted with a $5-\mathrm{mL}$ mixture of ethylacetate/2-propanol (93/7, vol/vol). The organic layer was transferred to another glass tube, and then evaporated to dryness under vacuum. The residue was reconstituted with a 200- $\mu \mathrm{L}$ mixture of $0.01 \mathrm{M}$ acetate buffer $(\mathrm{pH}$ $4.0) /$ methanol (92/8, vol/vol), and a portion (20 $\mu \mathrm{l})$ of the reconstituted solution was injected onto an HPLC (high-performance liquid chromatography) column. The HPLC system constituted of a pump (L-7100, Hitachi, Tokyo, Japan), an automatic sample injector (L-7200, Hitachi), a C18 reversed-phase column ( $5 \mu \mathrm{m}$, Capcell Pak UG120, 150 x 4.8, i. d., Shiseido, Tokyo, Japan), a UV detector (L-7400, Hitachi) set at 273 $\mathrm{nm}$, and a chromato-integrator (L-7500, Hitachi). The mobile phase was a mixture of $0.01 \mathrm{M}$ acetate buffer ( $\mathrm{pH} 4) /$ methanol (92/8, vol/vol) and was delivered at a flow rate of $1 \mathrm{~mL} / \mathrm{min}$. The column temperature was maintained at 30 oC using a temperature-controlled water bath. The recoveries of theophylline and its metabolites from urine were $>92 \%$, and within- and between-day coefficients of variation $(\mathrm{CV})$ were $<5 \%$ and $<7 \%$, respectively. The partial (fractional) metabolic clearance of theophylline to the respective metabolites was calculated by dividing the urinary excretion rates of the metabolites during the respective urine collection period by the serum theophylline concentration 
Table 1. Demographic data and serum data of pediatric patients who received theophylline with and without low-dose macrolide antibiotics

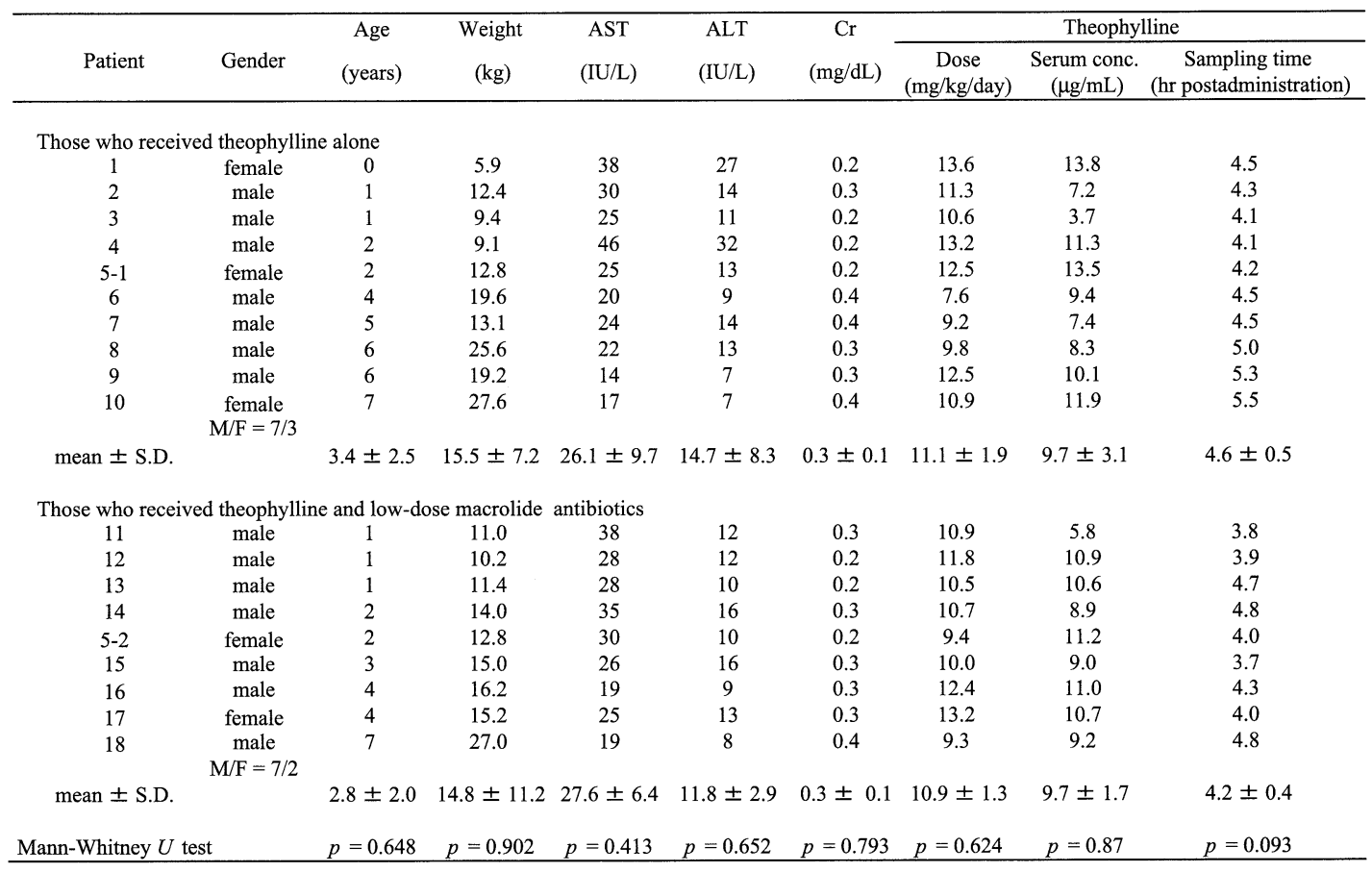

$\mathrm{AST}=$ asparate aminotransferase, $\mathrm{ALT}=$ alanine aminotransferase, $\mathrm{Cr}=$ creatinine

of each child. We assumed that the rate of metabolite formation from theophylline equals the rates of the appearance of metabolites in urine and that the metabolites are eliminated into urine without further metabolism. The renal clearance of theophylline was calculated by dividing the urinary excretion rate of theophylline by serum concentrations during the sampling period. Because the molecular weights of the respective theophylline metabolites and theophylline differ, the concentrations of the urinary metabolites were adjusted to the molar equivalent of theophylline.

\section{Statistical analysis}

All data are presented as mean \pm standard deviation (SD). Statistical differences in the means of the clinical variables and the parameters of theophylline disposition between the macrolide-antibiotic-treated and control groups were examined by the Mann-Whitney U test. A $p$ value of $<0.05$ was considered to indicate statistically significant difference.

\section{Results}

The demographic data of the children who participated in this study are shown in Table 1. No significant differences were observed in any demographic parameters (e.g., age and body weight) between the macrolide-antibiotic-treated and control groups. Among the nine children who underwent low-dose macrolide therapy, eight received erythromycin (i.e., $13.2 \pm 3.8$ $\mathrm{mg} / \mathrm{kg}$ body weight/day) and one received clarithromycin (i.e., $4.9 \mathrm{mg} / \mathrm{kg}$ body weight/day) at the doses shown in Table 2.

No significant difference in the oral dose of theophylline between the macrolide-antibiotictreated and control groups was observed (10.9 \pm 1.3 and $11.1 \pm 1.9 \mathrm{mg} / \mathrm{kg}$ body weight/day, respectively). The serum theophylline concentrations of the macrolide-antibiotic-treated and 
Table 2. Urinary data of theophylline and its metabolites with and without low-dose macrolide administration in pediatric patients

\begin{tabular}{|c|c|c|c|c|c|c|c|c|}
\hline \multirow[b]{2}{*}{ Patient } & \multirow{2}{*}{$\begin{array}{c}\text { Dose of macrolides } \\
(\mathrm{mg} / \mathrm{kg} / \text { day })\end{array}$} & \multirow{2}{*}{$\begin{array}{c}\text { Collection periods } \\
\text { of urine samples } \\
\text { (hours) }\end{array}$} & \multirow{2}{*}{$\begin{array}{c}\begin{array}{c}\mathrm{CLr} \text { of } \\
\text { theophylline } \\
(\mathrm{mL} / \mathrm{min} / \mathrm{kg})\end{array} \\
\end{array}$} & \multicolumn{4}{|c|}{ CLm of theophylline to metabolites } & \multirow[b]{2}{*}{$\begin{array}{l}\% \text { of dose } \\
\text { recovered }\end{array}$} \\
\hline & & & & $1 \mathrm{MU}$ & $\begin{array}{l}3 \mathrm{MX} \\
(\mathrm{mL} / \mathrm{mi}\end{array}$ & $\begin{array}{l}\text { DMU } \\
\text { in } / \mathrm{kg})\end{array}$ & Caffeine & \\
\hline \multicolumn{9}{|c|}{ Those who received theophylline alone } \\
\hline 1 & - & 2.1 & 0.028 & 0.041 & 0.023 & 0.087 & 0.000 & 2.3 \\
\hline 2 & - & 2.3 & 0.021 & 0.030 & 0.022 & 0.082 & 0.000 & 1.3 \\
\hline 3 & - & 2.3 & 0.040 & 0.054 & 0.041 & 0.112 & 0.001 & 1.2 \\
\hline $5-1$ & - & 0.8 & 0.233 & 0.142 & 0.133 & 0.384 & 0.011 & 4.7 \\
\hline 6 & - & 3.0 & 0.066 & 0.061 & 0.054 & 0.177 & 0.002 & 6.6 \\
\hline 7 & - & 1.5 & 0.361 & 0.192 & 0.167 & 0.632 & 0.007 & 9.9 \\
\hline 8 & - & 2.4 & 0.103 & 0.133 & 0.100 & 0.226 & 0.000 & 6.9 \\
\hline 9 & - & 12.0 & 0.132 & 0.136 & 0.085 & 0.235 & 0.007 & 34.6 \\
\hline 10 & - & 12.3 & 0.023 & 0.043 & 0.033 & 0.100 & 0.000 & 16.1 \\
\hline \multicolumn{9}{|c|}{ Those who received theophylline and low-dose macrolide antibiotics } \\
\hline 11 & erythromycin 9.1 & 1.9 & 0.053 & 0.158 & 0.115 & 0.218 & 0.000 & 3.3 \\
\hline 12 & clarithromycin 4.9 & 4.2 & 0.029 & 0.013 & 0.006 & 0.086 & 0.003 & 3.2 \\
\hline 13 & erythromycin 17.5 & 3.3 & 0.087 & 0.028 & 0.021 & 0.062 & 0.000 & 4.0 \\
\hline 14 & erythromycin 10.7 & 2.5 & 0.079 & 0.136 & 0.054 & 0.185 & 0.005 & 5.7 \\
\hline $5-2$ & erythromycin 10.2 & 0.7 & 0.388 & 0.210 & 0.152 & 0.833 & 0.009 & 7.4 \\
\hline 15 & erythromycin 10.0 & 9.8 & 0.053 & 0.064 & 0.048 & 0.150 & 0.001 & 16.7 \\
\hline 16 & erythromycin 18.5 & 5.9 & 0.071 & 0.039 & 0.030 & 0.117 & 0.001 & 8.1 \\
\hline 17 & erythromycin 16.4 & 11.9 & 0.080 & 0.067 & 0.042 & 0.128 & 0.001 & 18.5 \\
\hline 18 & erythromycin 13.0 & 6.0 & 0.057 & 0.061 & 0.045 & 0.135 & 0.001 & 10.7 \\
\hline mean \pm S.D. & $12.3 \pm 4.5$ & $5.1 \pm 3.7$ & $0.100 \pm 0.110$ & $0.086 \pm 0.067$ & $0.057 \pm 0.047$ & $0.213 \pm 0.237$ & $0.002 \pm 0.003$ & $8.6 \pm 5.7$ \\
\hline
\end{tabular}

$1 \mathrm{MU}=1$-methyluric acid, $3 \mathrm{MX}=3$-methylxanthine, $\mathrm{DMU}=1,3$-dimethyluric acid

$\mathrm{CLm}=$ metabolic clearance of theophylline to its respective metabolites, $\mathrm{CLr}=$ renal clearance of theophylline

control groups were comparable and were in the lower therapeutic range $(9.7 \pm 1.7$ and 9.7 $\pm 3.1 \mu \mathrm{g} / \mathrm{mL}$, respectively) at comparable blood sampling times (Table 1). No appreciable clinical signs or symptoms possibly attributable to theophylline toxicity were observed in the children during the study period.

No significant differences were observed in the partial metabolic clearance of theophylline to its respective metabolites or in the renal clearance of theophylline between the two groups (Table 2).

\section{Discussion}

This study is the first to demonstrate that the oral administration of low-dose (i.e., $12.3 \pm$ $4.5 \mathrm{mg} / \mathrm{kg}$ body weight/day) 14 -membered ring macrolide antibiotics (i. e., erythromycin and clarithromycin) to pediatric patients unlikely elicits clinically relevant alterations in the sys- temic disposition of a slow-release formula of theophylline. Recently, these macrolide antibiotics have been shown to possess tissue reparative effects, independent of their antimicrobial activity, in chronic inflammatory sinopulmonary diseases (i.e., chronic sinusitis, asthma, panbronchiolitis, and cystic fibrosis) ${ }^{2)}$. Because certain 14-membered ring macrolide antibiotics (e.g., erythromycin and clarithromycin) have been implicated to produce clinically significant drug interactions with theophylline ${ }^{5)}$ () when they are administered at rather higher doses, there is great concern as to whether low-dose macrolide antibiotic therapy evokes a clinically relevant drug interaction with theophylline. Our data clearly indicate that this possibility in pediatric patients is remote.

Regarding serum theophylline concentrations, we measured them at 3.5 - 6 hours after the oral administration when their peaks are 
assumed to occur to clarify the inhibitory effect of erythromycin and clarithromycin. It is of interest to explain the apparent contradiction between previous studies ${ }^{5)}$ a) and ours regarding the inhibitory effect of erythromycin and clarithromycin on the systemic clearance of theophylline. Prince et al. ${ }^{12)}$ demonstrated that the administration of erythromycin at $1 \mathrm{~g}$ /day for 7 days decreased the systemic clearance of theophylline by $25 \%$. They recommended that theophylline dose be decreased by at least $25 \%$ in patients whose serum theophylline concentrations are maintained in the middle value or upper portion of the $10-20 \mu \mathrm{g} / \mathrm{mL}$ therapeutic range, when erythromycin is added to the therapeutic regimen. However, the doses of the macrolide antibiotics employed in previous studies [5, 6] including that of Prince et al. [12] (e.g., 1-2 g/day for adults and $20 \mathrm{mg} / \mathrm{kg}$ body weight/day for children) were approximately twofold greater than those employed in this study (13 mg/kg body weight/day for children). Because the inhibitory effect of macrolide antibiotics on CYP3A4 is dose-dependent [13], the low-dose macrolide antibiotic therapy employed in this study was not associated with appreciable changes in the disposition of theophylline.

Multiple CYP isoforms are involved in the hepatic metabolism of theophylline ${ }^{78}$. Previous studies demonstrated that CYP3A4, CYP2E1, and CYP1A2 are involved in DMU formation (i.e., 8-oxidation of theophylline). In addition, CYP1A2 is involved in the formation of 1- and 3-MX (1- and 3-demethylations of theophylline, respectively). Because erythromycin and clarithromycin are specific inhibitors of CYP3A4 [5], the metabolic clearance of theophylline to DMU in the macrolide-antibiotic-treated group should have been reduced compared with in the control group, provided that CYP3A4 had been significantly inhibited by low-dose macrolide antibiotic therapy. The observation that there was no significant difference in this parameter between the two groups (Tables 1 and 2) indi- cates that the inhibitory effect of low-dose macrolide antibiotic therapy on in vivo CYP3A4 activity is limited, if indeed present at all. The observation that multiple CYP isoforms other than CYP3A4 are also involved in DMU formation from theophylline is another possible explanation. In addition, no significant difference in the renal clearance of theophylline was observed between the two groups, indicating that low-dose macrolide antibiotic therapy does not alter the renal excretion of the drug significantly.

Because only a small number of patients were studied and a matched-pair case-control design was not adopted in the present study, we cannot exclude a possibility that the administration of 14-membered macrolide antibiotics at lower doses may elicit a small inhibitory effect on the hepatic metabolism of theophylline. Strictly speaking, a matched-pair case control study is required to confirm the inhibitory effect of low-dose macrolide antibiotics. Nevertheless, our data suggest that a categorical recommendation for a dosage reduction of theophylline should not be required for most patients.

\section{Acknowledgments}

The authors thank Mr. Kenichiro Fukuda and Mr. Paul Arenson for help in manuscript preparation.

A preliminary report was presented at the 36th Annual Meeting of the Japanese Society of Pediatric Pulmonology, 2003 and the 54th Annual Meeting of the Japanese Society of Allergology, 2004.

\section{References}

1) Gal P, Reed MD 2004 Medications. In : Behrman RE, Kliegman RM, Jenson HB (eds) Nelson textbook of pediatrics. 17th ed. Philadelphia, W. B. Saunders, pp 2432-2501

2) Garey KW, Alwani A, Danziger LH, et al. : Tissue reparative effects of macrolide antibi- 
otics in chronic inflammatory sinopulmonary disease. Chest $123:$ 261-265, 2003.

3) Labro MT, el Benna J : Effects of anti-infectious agents on polymorphonuclear neutrophils. Eur J Clin Microbiol Infect Dis 10:124 $-131,1991$.

4) Feldman $\mathrm{C}$, Anderson $\mathrm{R}$, Theron AJ, et al. : Roxithromycin, clarithromycin, and azithromycin attenuate the injurious effects of bioactive phospholipids on human respiratory epithelium in vitro. Inflammation $21: 655-665$, 1997.

5) Westphal JF : Macrolide-induced clinically relevant drug interactions with cytochrome P-450A (CYP) 3A4 : an update focused on clarithromycin, azithromycin and dirithromycin. Br J Clin Pharmacol 50 : 285-295, 2000.

6) Weinberger $M$, Hendeles $L:$ Theophylline in asthma. N Engl J Med 334 : 1380-1388, 1996.

7) Sakar MA, Jackson BJ : Theophylline N-demethylation as probes for P4501A1 and P4501A2. Drug Metab Dispos 22:827-834, 1994.

8) Zhang Z-Y, Kaminsky LS : Characterization of human cytochromes P450 involved in theophylline 8-hydroxylation. Biochem Pharmacol 50 : 205-211, 1995.
9) Tateishi T, Asoh M, Yamaguchi A, et al. : Developmental changes in urine elimination of theophylline and its metabolites in pediatric patients. Pediatr Res 45 : 66-70, 1999.

10) Yamaguchi $A$, Tateishi $T$, Okano $Y$, et al. : Higher incidence of elevated body temperature or increased C-reactive protein level in asthmatic children showing transient reduction of theophylline metabolism. J Clin Pharmacol 40 : 284-289, 2000.

11) Kubo $M$, Odajima $Y$, Ishizaki $T$, et al. : Intraindividual changes in theophylline clearance during constant aminophylline infusion in children with acute asthma. J Pediatr 108: 1011-1015, 1986.

12) Prince RA, Wing DS, Weinberger MM, et al. : Effect of erythromycin on theophylline kinetics. J Allergy Clin Immunol 68 : 427-431, 1981.

13) Ushiama H, Echizen $H$, Nachi $S$, et al. : Dosedependent inhibition of CYP3A activity by clarithromycin during Helicobacter pylori eradication therapy assessed by changes in plasma lansoprazole levels and partial cortisol clearance to $6 \beta$-hydroxycortisol. Clin Pharmacol Ther 61 : 574-582, 2002. 